Article

\title{
Copolymerized Natural Fibre from the Mesocarp of Orbignya phalerata (Babassu Fruit) as an Irrigating-Fertilizer for Growing Cactus Pears
}

\author{
Ricardo Edvan ${ }^{1, *}\left(\mathbb{D}\right.$, Mariane Sá $^{1}$, Regina Magalhães ${ }^{1}$, Rafael Ratke ${ }^{2} \mathbb{D}$, Heldeney R. Sousa ${ }^{3}$, \\ Lucas Mateus Lima Neri ${ }^{3}$, Edson C. Silva-Filho ${ }^{3, *(\mathbb{D}}$, Jose Pereira Filho ${ }^{4}$ and Leilson Bezerra ${ }^{4, *}$ \\ 1 Department of Animal Science, Federal University of Piauí, Bom Jesus, Piauí 64900000, Brazil; \\ marivieira_15@hotmail.com (M.S.); regina_zootec@yahoo.com (R.M.) \\ 2 Department of Agronomy, Federal University of Mato Grosso do Sul, Chapadão do Sul, \\ Mato Grosso do Sul 79560000, Brazil; rafael.ratke@ufms.br \\ 3 Chemistry Department, Campus Ministro Petrônio Portela, Federal University of Piauí, Teresina, \\ Piauí 64049550, Brazil; dine.17@hotmail.com (H.R.S.); luslima_neris@hotmail.com (L.M.L.N.) \\ 4 Center of Health and Agricultural Technology, Federal University of Campina Grande, Patos, \\ Paraiba 58708110, Brazil; jmorais@cstr.ufcg.edu.br \\ * Correspondence: edvan@ufpi.edu.br (R.E.); edsonfilho@ufpi.edu.br (E.C.S.-F.); leilson@ufpi.edu.br (L.B.)
}

Received: 28 May 2020; Accepted: 21 July 2020; Published: 29 July 2020

\begin{abstract}
Cactus pears face challenges due to global climate change, which is leading to in-depth research to monitor and increase their water activity. The objective of this study was to evaluate the use of the natural test hydrogel (TH) from Orbignya phalerata fibre as nutrients and water for growing cactus pear genotypes ("Baiana" and "Doce" [Nopalea cochenillifera], 'Gigante' [Opuntia fícus-indica], and "Mexican Elephant Ear" [Opuntia stricta]) compared to the use of commercial hydrogel $(\mathrm{CH})$, which is based on polymers composed of polyacrylamide, and a treatment without the use of hydrogel (WH). A completely randomized design was used, in a factorial scheme $(4 \times 3)$, with four genotypes of cactus pear and three forms of hydration, with five replications. The number and area of cladode was greatest $(p<0.01)$ in plants with $\mathrm{CH}$ and TH irrigation-fertilization in the 'Doce' cactus genotype. The dry biomass of the cladode and root in the 'Gigante' cactus genotype was greatest $(p<0.01)$ in the treatments with $\mathrm{CH}$ and TH irrigation-fertilisation. The 'Baiana', 'Doce', and 'Gigante' cactus genotypes exhibited more $(p<0.01)$ dry matter content with the TH irrigation-fertilisation. The highest $(p<0.01)$ neutral detergent fibre content was observed in the 'Baiana' and 'Doce' cactus genotypes when irrigation occurred with $\mathrm{WH}$ treatment, and the highest acid detergent fibre content in the 'Gigante' genotype. The copolymerized natural fibre from the mesocarp of Orbignya phalerata (babassu fruit) induced a better growth and chemical composition of cactus pear genotypes than the hydrogel based on polymers composed of polyacrylamide.
\end{abstract}

Keywords: cactus; fertilization; irrigation; polyacrylamide; polymers

\section{Introduction}

Polymers composed of polyacrylamide, called hydrogels, are available on the market [1] and are used as substrates to cultivate plants. This type of hydrogel is already widely used in planting and cultivation in agriculture and forestry [2], with the main objective of supplying water slowly to the roots of plants when water is scarce in the soil [3,4], thus meeting the water needs of plants in critical periods. According to Cock et al. [5], hydrogels developed with biodegradable polymers such as starch, chitosan, and modified natural fibers, cross-linked with potassium acrylate and acrylamide, are an interesting novelty for plant development. The use of natural plant fibers in the production of hydrogels will 
allow substitution of synthetic compounds such as polyacrylamide polymers, for ecologically more sustainable products with lower production costs [6,7].

Natural fibers are among the most abundant polymers in nature [8] and are easily processed and biodegradable [7], thus hydrogels with natural fibers are an alternative that can reduce the cost of production and is environmentally friendly. The Orbignya phalerata is a tropical palm tree in Brazil [9] that produces a fruit called babassu. About 200,000 tons per year of this nut is gown to produce 70,000 tons of oil. The babassu coconut has a fibrous, lignocellulolytic epicarp, comprising $15 \%$ of the dry weight of the fruit. The mesocarp is a light brown layer, located under the epicarp, which is to $20 \%$ of the dry weight of the fruit [10]. Through the copolymerization technique and other physical and chemical processes, such as graphitization, the natural fiber of the mesocarp of the O. phalerata fruit can be used in the production of hydrogel.

The hydrogel produced from O. phalerata fiber, in addition to providing water, may also provide plant fertilizers. Supplying of fertilizers through the hydrogel is an efficient alternative because water and nutrients are released slowly into the soil, thus preventing leaching [11].

The Food and Agriculture Organization of the United Nations [12] recognizes the potential of cactus pear and its importance for the development of arid and semi-arid regions, especially in developing countries, through the economic exploitation of various species, with sustainable consequences for the environment and food security. With the possibility of providing various products and by-products, for human and animal nutrition, human medicine, the cosmetics industry, and the production of natural additives, the cactus pear represents an alternative income for those who live in arid and semi-arid regions in different parts of the world [13]. Therefore, cactus pear cultivation has great economic importance for regions with a dry climate, for both the agricultural and livestock sectors [14-16]. Among the species of cactus pear most used in animal feed in dry regions are the species Nopalea cochenillifera and the species of the genus Opuntia [16].

Thus, use of a hydrogel in cactus pear irrigation-fertilization can provide more growth and ensure productivity, increasing food production in arid regions. Thus, we hypothesized that the use of the natural fiber of $O$. phalerata in the production of a hydrogel would provide greater growth and better chemical composition in cactus pear plants than the commercial hydrogel based on polymers composed of polyacrylamide. The objective of this study was to evaluate the use of the copolymerized natural fiber from the mesocarp of Orbignya phalerata (babassu fruit) as nutrients and water for the growth and chemical composition of four cactus pear genotypes, comparing with the commercial hydrogel from a polyacrylamide polymer compound, as well as control without any hydrogel (three irrigation-fertilization systems).

\section{Materials and Methods}

\subsection{Location and Experimental Design}

The experiment was carried out in a greenhouse located in the municipality of Bom Jesus, Piaui State, Brazil, with geographical coordinates $09^{\circ} 04^{\prime} 28^{\prime \prime}$ South, $44^{\circ} 21^{\prime} 31^{\prime \prime}$ West and an average altitude of $277 \mathrm{~m}$. The region's climate is classified as BSh according to the 1936 Köppen classification, with dry winters and rainy summers [17].

A completely randomized design was used, with five repetitions, in a factorial scheme $(4 \times 3)$, with four genotypes of cactus pear ("Baiana" and "Doce" [Nopalea cochenillifera], "Gigante" [Opuntia ficus-indica] and "Mexican Elephant Ear" [Opuntia stricta]) and three irrigation-fertilization systems [control without hydrogel $(\mathrm{WH})$ and two types of soil irrigation-fertilization (commercial hydrogel- $\mathrm{CH}$ and test hydrogel-TH)]. Each experimental unit consisted of a plastic pot containing $9.0 \mathrm{~kg}$ of soil with a plant; a total of 60 pots were used. 


\subsection{Test Hydrogel Production and Physicochemical Characteristics of Test and Commercial Hydrogels}

To produce the $\mathrm{TH}$, a sample of $2.0 \mathrm{~g}$ of babassu coconut mesocarp was dispersed in $30.0 \mathrm{~mL}$ of water, under agitation and nitrogen atmosphere to decrease the oxygen inhibiting effect in the radical polymerization reaction. Next, $0.024 \mathrm{~g}$ of potassium phosphate and $2.10 \mathrm{~g}$ of acrylamide monomer were added to the supernatant, then $0.016 \mathrm{~g}$ of KPS initiator, $0.024 \mathrm{~g}$ of $N^{\prime} N^{\prime}$-methylenebisacrylamide, and $100 \mathrm{mg}$ of potassium bicarbonate. After $5 \mathrm{~min}$ of stirring and bubbling with nitrogen, $100.0 \mu \mathrm{L}$ of the TEMED accelerator was added. The system was closed and kept under nitrogen and stirring until reaching the gel point. Thus obtained, the gel was washed in a 30\% methanol/water solution to remove the acrylamide homopolymer, then it was dried by lyophilization, until a constant mass. The synthesized gels $(1.0 \mathrm{~g})$ were subjected to an alkaline hydrolysis reaction with $40.0 \mathrm{~mL}$ of $\mathrm{NaOH}$ $(0.5 \mathrm{~mol} / \mathrm{L})$ to convert their amide groups into carboxylate, then they were washed and lyophilized. All reagents used were obtained from Aldrich (São Paulo, Brazil), with an analytical grade, without prior treatment. The mesocarp was kindly provided by the company BabCoall (Teresina, Brazil).

For analysis and comparison between $\mathrm{TH}$ and $\mathrm{CH}$ (Table 1), visual analysis was performed to identify the colour, and water solubility was verified. Particle size was measured with a caliper, humidity determined by thermal analysis, on the SDT-600 equipment from TA-Instruments (New Castle, DE, USA) under nitrogen flow. The ionic character of the hydrogel was subjected to the test of different $\mathrm{pH}$ values (acidic and basic), obtaining a better behavior of the material in the basic medium (anionic carboxylate groups).

Table 1. Physicochemical characteristics of hydrogels.

\begin{tabular}{lcc}
\hline \multicolumn{1}{c}{ Characteristics } & Commercial Hydrogel $\mathbf{( C H})^{\mathbf{1}}$ & Test Hydrogel (TH) $^{\mathbf{2}}$ \\
\hline Ingredient & Polyacrylamide super absorbent & Mesocarp of babassu coconut reticulated with acrylamide \\
Particle size & $0.5-3 \mathrm{~mm}$ & $5-10 \mathrm{~mm}$ \\
Ionicity & Anionic & Anionic \\
Moisture & $10 \%$ & $6.4 \%$ \\
Density & $0.8 \mathrm{~g} / \mathrm{cm}$ & $-/-$ \\
Colour & White & Brown \\
Form & Granulated solid & Granulated solid \\
Solubility in water & Insoluble & Insoluble \\
\hline
\end{tabular}

${ }^{1}$ Commercial name Hydroplan-EB/HyA; Polymers composed of polyacrylamide superabsorbent. ${ }^{2}$ Copolymerized natural fiber from the mesocarp of Orbignya phalerata (babassu fruit).

\subsection{Characterizations}

The lyophilized hydrogel of the mesocarp reticulated with acrylamide with fertilizer added was characterized by scanning electron microscopy (SEM) and thermal analysis (TG/DTG).

\subsubsection{Scanning Electron Microscopy (SEM)}

The micrographs were performed using a scanning electron microscope (SEM) with a field emission gun, brand FEI, model Quanta FEG 250, with acceleration voltage from 1 to $30 \mathrm{kV}$, equipped with EDS of SDD (Silicon drift detectors), Ametek brand, model HX-1001, Apollo X-SDD detector. The analysis was carried out at the Interdisciplinary Laboratory of Advanced Materials (LIMAV) of the Federal University of Piaui. To perform the micrographs, the sample was fixed on an aluminum substrate (stub) using double-sided carbon adhesive tape and covered with $\mathrm{Au}$ in the metallizer, Quorum brand, model Q150R, for $30 \mathrm{~s}$, at $20 \mathrm{~mA}$, by plasma generated in argon atmosphere.

\subsubsection{Thermogravimetric Analysis (TG and DTG)}

Thermogravimetric analysis: TG—-thermogravimetry and DTG—-derived thermogravimetry, were performed on TA Instruments SDT-Q600 Simultaneous (Interdisciplinary Laboratory for Advanced Materials-LIMAV), with the objective of evaluating thermal stability and variations in mass and energy as a function of temperature. The analysis was carried out under an argon atmosphere, with a flow of 
$100 \mathrm{~mL} / \mathrm{min}$ and heating speed of $10^{\circ} \mathrm{C} / \mathrm{min}$, in a temperature range of 25 to $800^{\circ} \mathrm{C}$, from the alumina sample support.

\subsection{Hydrogel Irrigation-Fertilisation}

This study compared the application of a test hydrogel (TH), added with nutrients. The TH was based on the mesocarp of the babassu palm tree (O. phalerata) and was produced through the co-polymerization process. Each gram of $\mathrm{TH}$ contained $0.5 \% \mathrm{~K}_{3} \mathrm{PO}_{4}$, in the proportion of $67 \% \mathrm{~K}$ and $33 \% \mathrm{P}$. The $\mathrm{TH}$ had a swelling capacity of $1100 \mathrm{~g}$ of $\mathrm{H}_{2} \mathrm{O} / \mathrm{g}$ of hydrogel, and it was non-toxic. The conditions used for the swelling test were $27 \pm 2{ }^{\circ} \mathrm{C}$ and the $\mathrm{pH}$ was $7.0 \pm 0.2$.

The commercial hydrogel $(\mathrm{CH})$ used was a hydrogel already commercialized based on copolymer of acrylamide and potassium acrylate of the Hydroplan-EB (SAP) ${ }^{\circledR}$ brand. Both irrigation-fertilization hydrogels were applied to the soil for planting, already hydrated with the equivalent to $400 \mathrm{~L}$ for each $\mathrm{kg}$ of hydrogel, following the recommendation of the commercial hydrogel. In treatments with the $\mathrm{CH}$ and $\mathrm{WH}$, the equivalent of the minerals ( $\mathrm{K}$ and $\mathrm{P}$ ) existing in the $\mathrm{TH}$ was applied, using as a source of simple superphosphate $\left(18 \% \mathrm{P}_{2} \mathrm{O}_{5}\right.$ and $\left.20 \% \mathrm{Ca}^{2+}\right)$ and potassium chloride $\left(60 \% \mathrm{~K}_{2} \mathrm{O}_{5}\right)$. In the treatment with $\mathrm{TH}$, the equivalent of calcium was applied with hydrated lime $\left(46 \% \mathrm{Ca}^{2+}\right)$. These treatments were diluted in water to facilitate application, with the aid of a syringe, placed in the soil at the time of planting.

\subsection{Experimental Units}

The experimental units consisted of plastic pots $(27.5 \mathrm{~cm}$ top width, $22.1 \mathrm{~cm}$ bottom width, $24.7 \mathrm{~cm}$ height/9.0 L capacity, Nutriplan ${ }^{\circledR}$, São Paulo, Brazil) containing dystrophic red-yellow Latosol soil associated with quartz sand [18], with sandy physical characterization (clay: $220 \mathrm{~g} / \mathrm{kg}$; silt: $50 \mathrm{~g} / \mathrm{kg}$; and sand $720 \mathrm{~g} / \mathrm{kg}$ ), collected at a depth of 0 to $0.20 \mathrm{~m}$ in an area of native forest in Brazil close to the greenhouse. After collection, the soil was sieved in a $6.00 \mathrm{~mm}$ diameter metal mesh to remove impurities.

The correction of acidity and fertilization of the soil were based on the chemical analysis of the soil, which presented the following chemical characteristics: $4.00 \mathrm{pH}$ in water; $3.46 \mathrm{mg} / \mathrm{dm}$ phosphorus (P); $25.30 \mathrm{mg} / \mathrm{dm}$ potassium (K); $0.16 \mathrm{cmolc} / \mathrm{dm}^{3}$ calcium (Ca); $0.05 \mathrm{cmolc} / \mathrm{dm}^{3}$ magnesium $(\mathrm{Mg})$; $<0.30 \mathrm{cmolc} / \mathrm{dm}^{3}$ aluminum (Al); $4.62 \mathrm{cmolc} / \mathrm{dm}^{3}$ hydrogen + aluminum $(\mathrm{H}+\mathrm{Al}) ; 0.22 \mathrm{cmolc} / \mathrm{dm}^{3} \mathrm{sum}$ of bases (SB); $4.84 \mathrm{cmolc} / \mathrm{dm}^{3} \mathrm{CTC}$ at $\mathrm{pH} 7.0(\mathrm{~T}) ; 32.6 \%$ base saturation $(\mathrm{V})$; and $0.2 \%$ saturation by aluminum (M).

The soil acidity was corrected by applying a dose equivalent to $2 \mathrm{t} / \mathrm{ha}$ of limestone filler (PRNT $92 \%$; Dimy ${ }^{\circledR}$, São Paulo, Brazil), calculated to increase the base saturation to $45 \%$. To correct potassium levels, potassium chloride $\left(60 \% \mathrm{~K}_{2} \mathrm{O}\right)$ was used as a potassium source, applying the equivalent of $40 \mathrm{~kg}$ of $\mathrm{K}_{2} \mathrm{O} /$ ha. To correct phosphorus levels, simple superphosphate $\left(18 \% \mathrm{P}_{2} \mathrm{O}_{5}\right.$ and $\left.20 \% \mathrm{Ca}^{2+}\right)$ was applied at $90 \mathrm{Kg}$ of $\mathrm{P}_{2} \mathrm{O}_{5} / \mathrm{ha}$. In addition, the equivalent of $100 \mathrm{~kg}$ of $\mathrm{N} / \mathrm{ha}$ nitrogen in the form of urea $(45 \% \mathrm{~N})$ was applied. All soil corrections and fertilizations followed recommendations by Martha Jr. et al. [19]. The fertilizers were diluted in water and applied to the soil. In addition, K and P correction was also performed, for treatments with commercial hydrogel and without hydrogel, as previously described.

The cactus pear cladodes used for planting in plastic pots were collected at the Federal University of Piaui. The cladodes had a healthy appearance and dark green color, were free from pests and diseases, and had similar ages and weights according to each genotype. The intermediate part of the plant cladodes was used, discarding the young and old cladodes. After selection, they were placed in a shaded place for healing, and ten days after the harvest, they were planted in the experimental units (pots). At the time of planting, the irrigation-fertilization hydrogels were applied according to the treatments; $0.4 \mathrm{~g}$ hydrogel/pot (equivalent to $20 \mathrm{~kg}$ per hectare) was applied, following the recommendation of the $\mathrm{CH}$ for sandy soils (72\% sand in physical composition). The irrigation-fertilization hydrogels were placed in the bottom of each pot and already hydrated with water (Figure 1). 
a)

b)
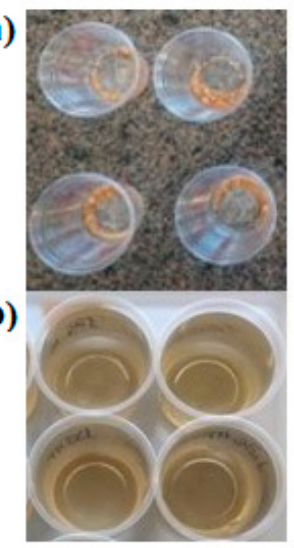

c)

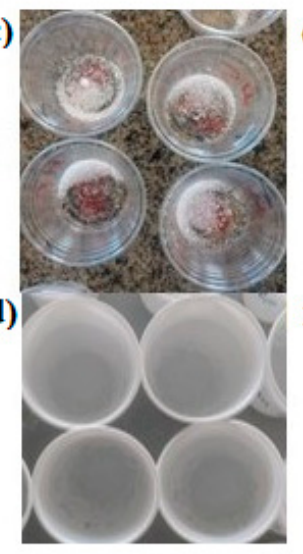

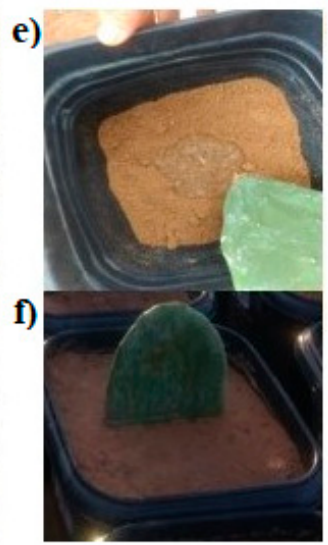

Figure 1. (a) Test hydrogel (TH); (b) TH hydrated; (c): commercial hydrogel (CH); (d) CH hydrated; (e) application of hydrogels to the soil before planting; (f) cactus pear planted with hydrogels.

To determine irrigation-fertilization, the pot capacity method, described by Casaroli and Lier [20], was applied. After determining the plastic pots capacity, irrigation was carried out through the daily weighing of the pots, measuring water stress on the plants, until a level of $10 \%$ of the field capacity was reached, with the aim to verify the potential of the hydrogels.

\subsection{Analysis of Cactus Pear Growth}

The cactus pear genotypes growth was analyzed at out 180 days after planting. The following morphometric observations were made to characterize the growth of the plants: number of cladodes, obtained by counting the cladodes and the cactus pear height, measured with a tape measure $(100 \mathrm{~cm})$ from the soil surface to the apex of the highest cladode.

The length (horizontal part) and width (vertical part) of the cladodes were measured in the central region of the cladodes with the aid of a measuring tape $(100 \mathrm{~cm})$, to obtain the cactus cladode area $\left(\mathrm{cm}^{2} /\right.$ plant) using the equation AC $=$ length $\times$ width $\times 0.632$, as described by Cortázar and Nobel [21]. To harvest the plant, a close-to-ground cut was made with the aid of a machete (Tramontina ${ }^{\circledR}$, Carlos Barbosa, Brazil).

The harvested material was weighed in the field, to obtain the total green biomass. Then it was placed in a forced ventilation oven at $65^{\circ} \mathrm{C}$, where it remained for $72 \mathrm{~h}$, to obtain the dry weight according to the Association of Official Analytical Chemists (AOAC; method 967.03) [22]. Soon after, the dry samples were weighed to determine the dry biomass of cladodes (g/plant). In each pot, the roots were collected, washed with running water, and dried on paper towels to separate the soil contained in each pot. The samples were packed in paper bags and weighed, to obtain the fresh biomass. Then, they were taken to the forced ventilation oven to dry, at a temperature between 55 and $65^{\circ} \mathrm{C}$, until constant weight. Subsequently, the material was weighed on a precision scale to obtain the dry biomass of roots (g/plant).

\subsection{Chemical Composition Analysis}

Laboratory analyses were performed to determine the chemical composition (in triplicate) according to the recommendations of the AOAC [22]. Dry matter-DM (method 967.03), crude ash-CA (method 942.05), crude protein-CP (method 981.10), and ether extract—EE (method 920.29) were determined. The neutral detergent fiber (NDF) and acid detergent fiber (ADF) were determined according to the methodology proposed by Van Soest et al. [23], with the NDF residue incinerated in an oven at $600{ }^{\circ} \mathrm{C}$ for $4 \mathrm{~h}$ for the correction of ash and protein contamination. The samples were treated with thermostable alpha-amylase without the use of sodium sulfite. To determine acid detergent lignin (ADL), the ADF residue was treated with $72 \%$ sulfuric acid. 


\subsection{Statistical Analysis}

The experimental employed a randomized block design, arranged in a $4 \times 3$ factorial, with four cactus pear genotypes and three irrigation-fertilization systems. The following mathematical (Equation (1)) model was used:

$$
Y i j k=\mu+\alpha i+\beta j+(\alpha \beta) i j+k+e i j k
$$

where Yijk is the observed value; $\mu$ is overall average of the treatment; $\alpha i$ is effect of cactus pear genotypes $i ; i$ is "Baiana" and "Doce" (N. cochenillifera), "Gigante" (O. ficus-indica), and "Mexican Elephant Ear" (O. stricta); $\beta j$ is effect of irrigation-fertilization system $\mathrm{j} ; \mathrm{j}$ is control or WH and two other types of soil irrigation-fertilization $(\mathrm{CH}$ and $\mathrm{TH}) ;(\alpha \beta) i j$ is the effect of the interaction of the cactus pear genotypes and irrigation-fertilization system; and eijk is random error associated with each observation.

The studied variables were statistically treated by analysis of variance (ANOVA), followed by Scott-Knott test using software SISVAR ${ }^{\circledR}$ version 5.0 [24]. All analyses were performed considering significant for $p$-value $\leq 0.05$.

\section{Results}

Figure 2 illustrates the results of the thermal analysis (TG and DTG) for the babassu mesocarp (a) and for the lyophilized hydrogel of the mesocarp reticulated with acrylamide with fertilizer added (b).

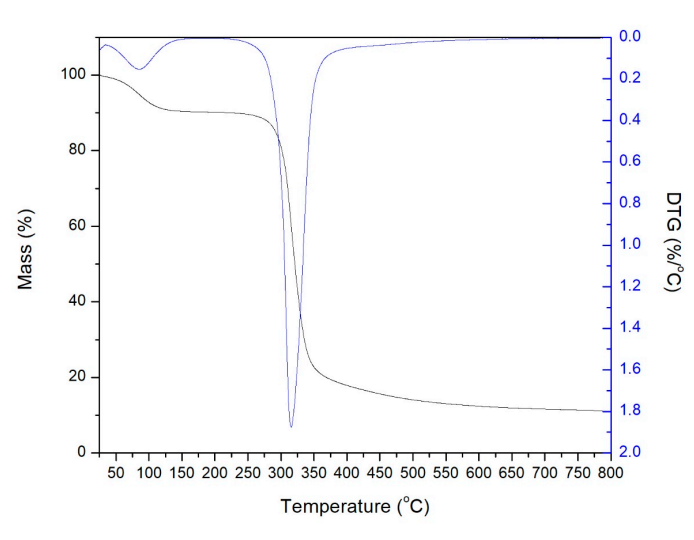

(a)

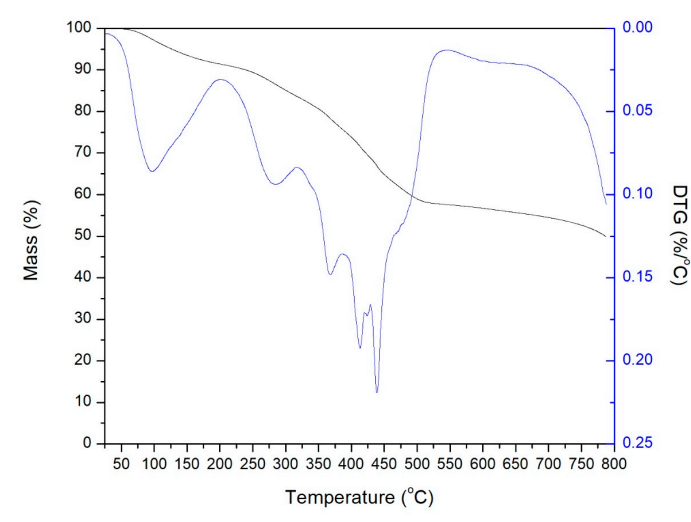

(b)

Figure 2. TG and DTG curves: (a) babassu mesocarp and (b) lyophilized hydrogel of the mesocarp reticulated with acrylamide with fertilizer added.

Figure 3 presents the scanning electron microscopy (SEM) of the lyophilized hydrogel of the mesocarp reticulated with acrylamide with fertilizer added.

There was an interaction $(p<0.01)$ between cactus pear genotypes and irrigation-fertilization sources for all plant growth characteristics (Table 2). A greater $(p<0.01)$ number of cladodes was achieved for the cactus pear irrigated-fertilized with the commercial hydrogel $(\mathrm{CH})$ and test hydrogel (TH) with the "Doce" cactus genotype, with $5.5 \pm 0.3$ and $6.1 \pm 0.3$ cladodes per plant. The treatment without hydrogel $(\mathrm{WH})$ produced fewer cladodes for all cactus pear genotypes. The "Gigante" cactus genotype grew more cladodes when cultivated with $\mathrm{TH}$ irrigation-fertilization. There was no difference $(p>0.01)$ between the irrigation-fertilization sources for the "Mexican Elephant Ear" genotype. 


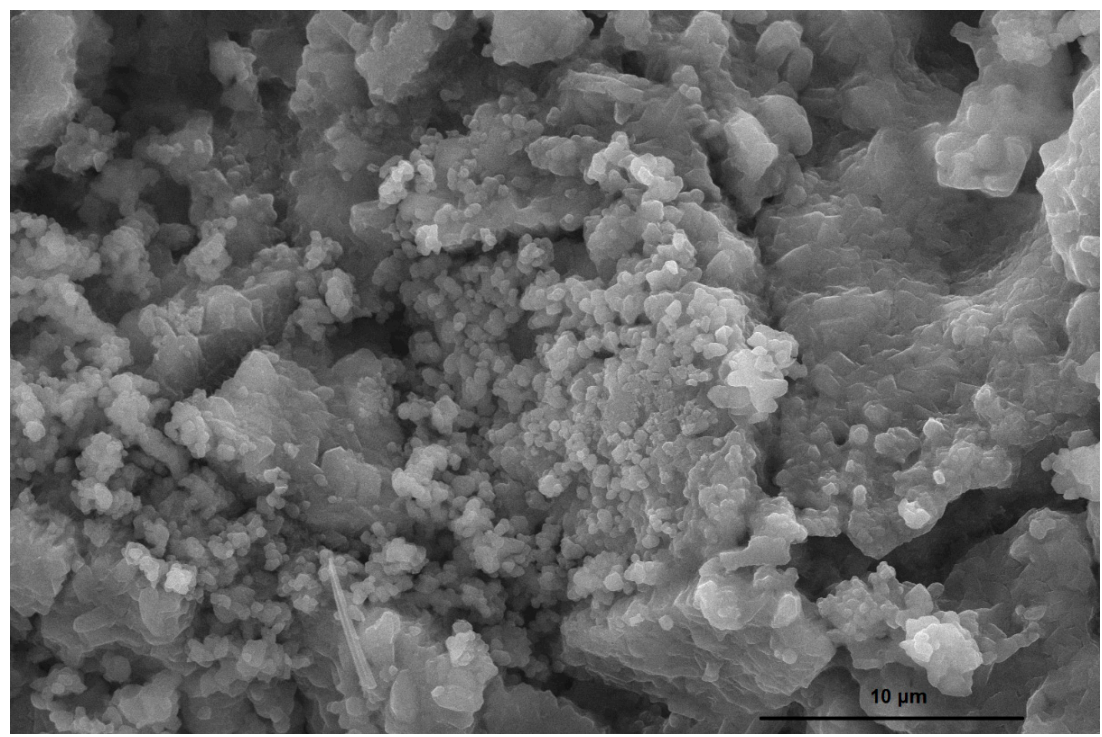

Figure 3. Scanning electron micrograph (SEM) of lyophilized hydrogel from babassu coconut mesocarp reticulated with acrylamide.

Table 2. Growth characteristic of four cactus pear genotypes under different forms of hydrogel irrigation-fertilization.

\begin{tabular}{|c|c|c|c|c|c|c|c|c|}
\hline \multirow{2}{*}{ Genotypes (G) } & \multicolumn{3}{|c|}{ Hydrogel Irrigation-Fertilization (HI) } & \multirow{2}{*}{ Mean } & \multicolumn{3}{|c|}{ Effect ( $p$-Value $)^{1}$} & \multirow{2}{*}{ SEM $^{2}$} \\
\hline & Without & Commercial & Test $^{3}$ & & HI & Genotype & $\mathrm{HI} \times \mathrm{G}$ & \\
\hline \multicolumn{9}{|c|}{ Number of cladode (unit) } \\
\hline 'Baiana' & $2.1 \mathrm{bA}$ & 3.3aB & $3.5 \mathrm{aC}$ & 2.6 & $<0.01$ & $<0.01$ & $<0.01$ & 0.3 \\
\hline 'Doce' & $2.4 \mathrm{bA}$ & $5.5 \mathrm{aA}$ & $6.1 \mathrm{aA}$ & 4.5 & & & & \\
\hline ‘Gigante' & $2.2 \mathrm{cA}$ & $3.0 \mathrm{bB}$ & $4.5 \mathrm{aB}$ & 3.1 & & & & \\
\hline 'MEE' 4 & $2.0 \mathrm{aA}$ & $1.5 \mathrm{aC}$ & $2.0 \mathrm{aC}$ & 1.8 & & & & \\
\hline Mean & 2.0 & 3.3 & 3.7 & & & & & \\
\hline \multicolumn{9}{|c|}{ Cactus cladode area $\left(\mathrm{cm}^{2} /\right.$ plant $)$} \\
\hline 'Baiana' & $551 \mathrm{bA}$ & $1255 \mathrm{aB}$ & $1020 \mathrm{aB}$ & 746 & $<0.01$ & $<0.01$ & $<0.01$ & 185 \\
\hline 'Doce' & $314 \mathrm{bA}$ & $2060 \mathrm{aA}$ & $2479 \mathrm{aA}$ & 1617 & & & & \\
\hline ‘Gigante' & $796 \mathrm{cA}$ & $1206 b B$ & $1965 \mathrm{aA}$ & 1322 & & & & \\
\hline 'MEE' & $561 \mathrm{aA}$ & $478 \mathrm{aC}$ & $523 \mathrm{aC}$ & 439 & & & & \\
\hline Mean & 555 & 1225 & 1313 & & & & & \\
\hline \multicolumn{9}{|c|}{ Cactus pear height $(\mathrm{cm})$} \\
\hline 'Baiana' & $40.0 \mathrm{aC}$ & $38.9 \mathrm{aC}$ & $40.7 \mathrm{aB}$ & 39.8 & $<0.01$ & $<0.01$ & $<0.01$ & 2.2 \\
\hline 'Doce' & $37.0 \mathrm{bC}$ & $45.0 \mathrm{aB}$ & $42.3 \mathrm{abB}$ & 41.4 & & & & \\
\hline 'Gigante' & $72.5 \mathrm{aA}$ & $64.5 \mathrm{bA}$ & $53.0 \mathrm{cA}$ & 63.3 & & & & \\
\hline 'MEE' & $56.0 \mathrm{aB}$ & $36.5 b C$ & $36.6 \mathrm{bB}$ & 43.7 & & & & \\
\hline Mean & 51.3 & 46.2 & 43.6 & & & & & \\
\hline \multicolumn{9}{|c|}{ Dry biomass of cladode (g/plant) } \\
\hline 'Baiana' & $231 b C$ & $319 \mathrm{aB}$ & $364 \mathrm{aB}$ & 271 & $<0.01$ & $<0.01$ & $<0.01$ & 15 \\
\hline 'Doce' & $194 b D$ & $340 \mathrm{aB}$ & $346 \mathrm{aB}$ & 292 & & & & \\
\hline 'Gigante' & $434 \mathrm{bA}$ & $547 \mathrm{aA}$ & $546 a \mathrm{~A}$ & 542 & & & & \\
\hline 'MEE' & $262 \mathrm{aB}$ & $246 \mathrm{aC}$ & $240 \mathrm{aC}$ & 293 & & & & \\
\hline Mean & 346 & 363 & 341 & & & & & \\
\hline \multicolumn{9}{|c|}{ Dry biomass of root (g/plant) } \\
\hline 'Baiana' & $4.0 \mathrm{cA}$ & $10.3 \mathrm{aAB}$ & $6.8 \mathrm{bB}$ & 6.3 & $<0.01$ & $<0.01$ & $<0.01$ & 0.9 \\
\hline 'Doce' & $3.0 \mathrm{bA}$ & $7.0 \mathrm{aB}$ & 8.3aAB & 6.1 & & & & \\
\hline 'Gigante' & $5.0 \mathrm{bA}$ & $11.3 \mathrm{aA}$ & $9.6 \mathrm{aA}$ & 8.2 & & & & \\
\hline 'MEE' & $4.0 \mathrm{bA}$ & $9.7 \mathrm{aAB}$ & $11.4 \mathrm{aA}$ & 8.3 & & & & \\
\hline Mean & 4.0 & 9.5 & 8.2 & & & & & \\
\hline
\end{tabular}

${ }^{1}$ Means followed by different lowercase letters in the row and uppercase letters in the column differ statistically by the Scott-Knott test $p<0.05 .{ }^{2}$ SEM: standard error mean. ${ }^{3} \mathrm{TH}$ : Hydrogel produced from copolymerized natural fiber from the mesocarp of Orbignya phalerata (babassu fruit). ${ }^{4}$ MEE: "Mexican Elephant Ear". 
The "Doce" cactus pear genotype exhibited the largest $(p<0.01)$ area of the plant cladode with application of $\mathrm{CH}$ and TH irrigation-fertilization, obtaining $2060 \pm 185$ and $2479 \pm 185 \mathrm{~cm}^{2} /$ plant area, respectively. The treatment with TH obtained a greater area of plant cladode for the "Gigante" genotype. The "Mexican Elephant Ear" genotype showed no significant difference for the irrigation-fertilization source of the plant in relation to the area of the cladode.

The "Gigante" cactus genotype with WH irrigation-fertilization achieved a greatest $(p<0.01)$ plant height of $72.5 \pm 2.2 \mathrm{~cm}$. The "Doce" cactus genotype grew taller with the $\mathrm{CH}$ and TH treatments, at $45.0 \pm 2.2$ and $42.3 \pm 2.2 \mathrm{~cm}$, respectively. The "Mexican Elephant Ear" cactus genotype had greater height with the WH irrigation-fertilization treatment. However, the "Baiana" cactus genotype exhibited no effect $(p>0.01)$ in relation to the irrigation-fertilization of the plant.

For dry biomass of cladodes, the "Gigante" cactus genotype obtained a greater $(p<0.01)$ amount with the $\mathrm{CH}$ and $\mathrm{TH}$ irrigation-fertilization, at $547 \pm 15$ and $546 \pm 15 \mathrm{~g} /$ plant. The "Baiana" and "Doce" cactus genotypes presented more dry biomass of cladodes with the hydrogel treatments (CH and TH irrigation-fertilization). For the "Mexican Elephant Ear" genotype, there was no effect $(p>0.01)$ on dry biomass of cladodes with the different forms plant hydration. The highest values $(p<0.01)$ of dry biomass of roots were observed in the "Gigante" cactus genotype with the $\mathrm{CH}$ and TH irrigation-fertilization, at $11.3 \pm 0.9$ and $9.6 \pm 0.9 \mathrm{~g} / \mathrm{plant}$, as well as in the "Mexican Elephant Ear" genotype with the TH irrigation-fertilization, at $11.4 \pm 0.9 \mathrm{~g} /$ plant. In the "Doce" genotype, more dry biomass of roots was found with hydrogel treatments ( $\mathrm{CH}$ and $\mathrm{TH}$ irrigation-fertilization), and in the "Baiana" cactus genotype, it was greatest with the $\mathrm{CH}$ treatment.

The evaluation of the chemical composition (Table 3) observed an interaction $(p<0.01)$ between the cactus pear genotypes and irrigation-fertilization sources of the plant for dry matter (DM), neutral detergent fibre (NDF), and acid detergent fiber (ADF). The contents of crude ash (CA) and organic matter $(\mathrm{OM})$ were no effect $(p>0.05)$ for the different genotypes and hydration of the plant. However, for the crude protein $(\mathrm{CP})$ content, there was an isolated effect $(p<0.01)$ for the different cactus pear genotypes and irrigation-fertilization sources.

The "Baiana", "Doce", and "Gigante" cactus genotypes presented a dry matter content $(p<0.01)$ with the TH irrigation-fertilization of 65, 69, and $63 \mathrm{~g} / \mathrm{kg}$ DM, respectively. The "Mexican Elephant Ear" genotype achieved a higher DM content with $\mathrm{CH}$ irrigation-fertilization, obtaining $69 \mathrm{~g} / \mathrm{kg}$ when fed (Table 3). The "Baiana" and "Doce" cactus genotypes presented the highest NDF content with the WH irrigation-fertilization treatment, obtaining 296 and $324 \mathrm{~g} / \mathrm{kg}$ in DM basis, respectively. The greatest ADF content was observed for the "Gigante" cactus genotype with the WH irrigation-fertilization $(122 \mathrm{~g} / \mathrm{kg}$ in DM). The "Mexican Elephant Ear" genotype had greater CP content $(123 \mathrm{~g} / \mathrm{kg}$ in DM basis) than the other cactus pears genotypes, and the WH irrigation-fertilization obtained a higher $\mathrm{CP}$ concentration (113 $\mathrm{g} / \mathrm{kg}$ in DM basis) than $\mathrm{CH}$ and $\mathrm{TH}$. 
Table 3. Chemical composition of four cactus pear genotypes under different irrigation-fertilization sources.

\begin{tabular}{|c|c|c|c|c|c|c|c|c|}
\hline \multirow{2}{*}{ Genotypes (G) } & \multicolumn{3}{|c|}{ Hydrogel Irrigation-Fertilization (HI) } & \multirow{2}{*}{ Mean } & \multicolumn{3}{|c|}{ Effect ( $p$-Value $)^{1}$} & \multirow{2}{*}{ SEM $^{2}$} \\
\hline & Without & Commercial & Test $^{3}$ & & HI & Genotype & $\mathrm{HI} \times \mathrm{G}$ & \\
\hline \multicolumn{9}{|c|}{ Dry matter-DM (g/kg as fed) } \\
\hline ‘Baiana' & $57 \mathrm{Bb}$ & 66Аa & $65 \mathrm{Aa}$ & 63 & $<0.01$ & $<0.01$ & $<0.01$ & 1.0 \\
\hline ‘Doce' & $63 \mathrm{Ab}$ & 69Aa & $69 \mathrm{Aa}$ & 67 & & & & \\
\hline ‘Gigante' & 60Aa & $56 \mathrm{Bb}$ & 63Аа & 60 & & & & \\
\hline 'MEE' 4 & $56 \mathrm{Bb}$ & 69Aa & $56 \mathrm{Bb}$ & 60 & & & & \\
\hline Mean & 59 & 65 & 63 & & & & & \\
\hline \multicolumn{9}{|c|}{ Crude ash-CA (g/kg dry matter) } \\
\hline 'Baiana' & 195 & 183 & 177 & 154 & 0.55 & 0.45 & 0.44 & 4.5 \\
\hline ‘Doce' & 174 & 178 & 178 & 177 & & & & \\
\hline 'Gigante' & 173 & 173 & 181 & 176 & & & & \\
\hline 'MEE' 4 & 166 & 162 & 190 & 173 & & & & \\
\hline Mean & 177 & 174 & 182 & & & & & \\
\hline \multicolumn{9}{|c|}{ Organic matter-OM (g/kg dry matter) } \\
\hline 'Baiana' & 804 & 816 & 822 & 814 & 0.55 & 0.45 & 0.44 & 4.5 \\
\hline 'Doce' & 825 & 821 & 821 & 822 & & & & \\
\hline 'Gigante' & 826 & 826 & 818 & 823 & & & & \\
\hline 'MEE' 4 & 833 & 837 & 809 & 826 & & & & \\
\hline Mean & 822 & 825 & 817 & & & & & \\
\hline \multicolumn{9}{|c|}{ Crude protein-CP ( $\mathrm{g} / \mathrm{kg}$ dry matter) } \\
\hline 'Baiana' & 117 & 96 & 97 & $103 \mathrm{~B}$ & $<0.01$ & $<0.01$ & 0.10 & 2.1 \\
\hline 'Doce' & 94 & 89 & 89 & $90 \mathrm{C}$ & & & & \\
\hline ‘Gigante' & 105 & 97 & 95 & $99 \mathrm{~B}$ & & & & \\
\hline$' \mathrm{MEE}^{\prime} 4$ & 135 & 112 & 121 & $123 \mathrm{~A}$ & & & & \\
\hline Mean & $113 a$ & $98 b$ & $101 b$ & & & & & \\
\hline \multicolumn{9}{|c|}{ Neutral detergent fiber-NDF ( $\mathrm{g} / \mathrm{kg}$ dry matter) } \\
\hline 'Baiana' & 296Аа & $218 \mathrm{Bb}$ & $268 \mathrm{Ba}$ & 261 & $<0.01$ & 0.04 & $<0.01$ & 7.1 \\
\hline ‘Doce' & $324 \mathrm{Aa}$ & $227 \mathrm{Bb}$ & $240 \mathrm{Bb}$ & 264 & & & & \\
\hline 'Gigante' & $242 \mathrm{Bb}$ & $242 \mathrm{Bb}$ & 287Aa & 257 & & & & \\
\hline 'MEE' 4 & $255 \mathrm{Bb}$ & $281 \mathrm{Ab}$ & 316Аa & 284 & & & & \\
\hline Mean & 279 & 242 & 278 & & & & & \\
\hline \multicolumn{9}{|c|}{ Acid detergent fiber-ADF (g/kg dry matter) } \\
\hline 'Baiana' & $95 \mathrm{Ba}$ & $80 \mathrm{Bb}$ & $101 \mathrm{Aa}$ & 92 & $<0.01$ & $<0.01$ & $<0.01$ & 7.1 \\
\hline ‘Doce' & $95 \mathrm{Ba}$ & 90Ba & 102Aa & 96 & & & & \\
\hline 'Gigante' & $122 \mathrm{Aa}$ & $101 \mathrm{Ab}$ & $97 \mathrm{Ab}$ & 107 & & & & \\
\hline 'MEE' 4 & $89 \mathrm{Ba}$ & $86 \mathrm{Ba}$ & 91Aa & 89 & & & & \\
\hline Mean & 100 & 89 & 98 & & & & & \\
\hline
\end{tabular}

${ }^{1}$ Means followed by different lowercase letters in the row and uppercase letters in the column differ statistically by the Scott-Knott test $p<0.05 .{ }^{2}$ SEM: standard error mean. ${ }^{3}$ TH: Hydrogel produced from copolymerized natural fiber from the mesocarp of Orbignya phalerata (babassu fruit). ${ }^{4}$ MEE: 'Mexican Elephant Ear'.

\section{Discussion}

The thermogravimetric curve and the thermogravimetric derivative (Figure 2a) of the babassu coconut mesocarp indicates that the thermal decomposition of this material occurs in two stages, the first in the range of 35 to $150{ }^{\circ} \mathrm{C}$, with a $10 \%$ weight loss, which is related to the dehydration of the material (vaporization of physically adsorbed water) $[25,26]$.

The TG/DTG curves illustrate that two main thermal events occurred, the first in the range of 50 to $157^{\circ} \mathrm{C}$, with a mass loss of $6.4 \%$, and a maximum rate of loss in temperature of $96^{\circ} \mathrm{C}$, being associated with vaporization of physically adsorbed water.

The second thermal event occurred together with a series of secondary reactions (and decompositions) and extends to $544^{\circ} \mathrm{C}$, with a mass loss of $33.1 \%$, and a maximum decomposition temperature of $439^{\circ} \mathrm{C}$. This event is related to the initial degradation of the material, starting the depolymerization process, initially by breaking and volatilization of more superficial groups, followed by breaking and decomposition of larger groups [27], with little variation in mass after this temperature. The residual mass comes from the presence of the fertilizer. 
The micrograph of the lyophilized hydrogel of the mesocarp reticulated with acrylamide with fertilizer added is presented in Figure 3. After the crosslinking a change occurred, as the babassu mesocarp has a spherical shape, very similar to starch microscopy [28] and after modification, a heterogeneity in the size of the particles was caused by the crosslinking, followed by the absorption and lyophilization of the water. A similar result was observed in thermogravimetry with several mass events in very close regions, caused by different particle sizes, altering its stability, which is ideal for application in systems to control release of water and fertilizers on the soil. Its microstructure contains pores distributed by its extension, which greatly help in the process of water absorption by the material, with very varied porosities, caused by the size of the particles, generating an excellent benefit for the controlled release [29]. The smallest particles found in the image are the fertilizer added to the system.

The interaction between the cactus pear genotypes and the different forms to hydrate the plant demonstrates that the morphophysiological differences of the plants and the use of the irrigation-fertilization hydrogel, as well as the type of hydrogel, influenced the main growth characteristics of the cactus pear. The evaluated cactus pear genotypes have very different morphological characteristics [30]. Hydrogel cultivation achieves greater hydration of the plants and, with this, greater growth [31].

The main characteristic of the cactus pear "Doce" genotype is the greater number of cladodes compared to the other genotypes evaluated [32]. More cladodes were observed with the use of hydrogels ( $\mathrm{CH}$ and TH irrigation-fertilization), demonstrating the effect of these on cactus pear growth. An irrigation-fertilization hydrogel provides slow release of water and nutrients to the plant [33], stimulating growth of more cladodes when compared to WH irrigation-fertilization.

The TH produced with copolymerized natural fiber from the mesocarp of Orbignya phalerata (babassu fruit) exhibited potential, yielding a similar number of cladodes as $\mathrm{CH}$ irrigation-fertilization. Thus, natural fibers of O. phalerata have potential for production of hydrogels. According to Rodrigues et al. [34], natural fibers are abundant in nature, and their use is ecologically correct, in addition they can make low-cost products.

Both hydrogels produced a greater cladode area in cactus pear plants, which is mainly due to the water support provided by the hydrogel to the plants, since the plants were under water stress during the experimental period. The "Gigante" cactus genotype presented a greater number and area of cladodes with the use of the $\mathrm{TH}$, demonstrating the irrigation-fertilization potential of the hydrogel produced from natural fibres of $O$. phalerata. The best performance for this genotype with the use of TH irrigation-fertilization occurred due to the slow release of water to the plant, associated with nutrients $\mathrm{K}$ and $\mathrm{P}$ [35]. With the $\mathrm{CH}$ irrigation-fertilization, the amount of $\mathrm{K}$ and $\mathrm{P}$ related to the compound in TH was applied to the soil. Using slow-release fertilizers avoids the leaching and volatilisation processes of nutrients in the soil [36].

The "Gigante" cactus genotype had greater plant height with the WH irrigation-fertilization, due to the morphological characteristic of this plant, which is taller than the other specimens evaluated. Thus, the greater plant height with the WH treatment can been explained due to the lower number and area of cladodes obtained with this treatment. Cactus pears with greater cladode development and more cladodes tend to have a lower plant height $[37,38]$, which was what happened with the hydrogel treatments.

For the production of dry biomass of cactus pear cladodes, the "Gigante" cactus genotype obtained the highest biomass production due its large cladode size [39]. The "Baiana", "Doce" and "Gigante" cactus genotypes showed higher dry biomass of cladodes with treatments using hydrogel $(\mathrm{CH}$ and TH irrigation-fertilization). The use of natural O. phalerata fibers and commercial hydrogels for the cactus pears increased growth characteristics because they improved the slow availability of water and fertilizers for plants over the WH treatment.

The irrigation-fertilization source did not change the number, area, and dry biomass of cladodes in the "Mexican Elephant Ear" cactus pear genotype. This genotype did not grow efficiently from the hydrogel application compared to the other genotypes of cacti studied, which may be related to 
the fact that the "Mexican Elephant Ear" genotype using water more efficiently; therefore, it did not respond to hydrogels irrigation $[40,41]$.

The use of the irrigation-fertilization hydrogel also generated a greater amount of dry biomass of roots in the "Doce" and "Gigante" cactus genotypes, which presented better performance with the use of irrigation-fertilization hydrogels in the soil. The highest concentration of the root system of a cactus pear is in the superficial layer of the soil [42]. Cactus pears with a larger root system have greater production potential and withstand weathering conditions [43] as they have a greater capacity to absorb water and available nutrients in the soil [44].

The irrigation-fertilization hydrogel from copolymerized natural fiber from the mesocarp of Orbignya phalerata (babassu fruit) showed equal or better performance for the main growth characteristics of the evaluated cactus pears. The use of this type of natural fiber for hydrogel production has potential due to its availability [45] and economic and environmental advantage [46].

The greater dry matter (DM) content observed in the "Baiana", "Doce", and "Gigante" cactus genotypes with the use of TH irrigation-fertilization demonstrates that, this treatment facilitated greater accumulation of organic and mineral compounds in the tissues of the plants [33]. The greater DM content of the "Baiana", "Doce", and "Gigante" cactus genotypes is related to a higher total dry biomass accumulation, which is an important characteristic for animal production as it provides greater food availability, increasing food security for herds in dry regions [47].

Fiber is present in the cell wall of vegetables, formed primarily by cellulose, hemicellulose, lignin, protein, and other compounds. It has a priority function in ruminant nutrition, as a source of energy and to stimulate the fermentation processes [48-50]. The fiber digestion of forage is not constant for all animals or for all feeding conditions, varying from 135 to $780 \mathrm{~g} / \mathrm{kg}$ in DM basis, but the main variation is due to differences in the structure, chemical composition, and maturity. Mertens [37] and the National Research Council (NRC) [51] suggested that a diet should have an added crude fiber source in the proportion of 5 to $20 \%$ of DM and between 250 to $330 \mathrm{~g} / \mathrm{kg}$ of NDF and 100 to $150 \mathrm{~g} / \mathrm{kg}$ ADF to stimulate the maximum intake of DM and ruminal health. The $\mathrm{CH}$ and $\mathrm{TH}$ irrigation-fertilization reduced ADF and increased NDF. According to Carvalho et al. [52], the cactus pear has a low fiber content, which can reduce the rumen $\mathrm{pH}$ and cause degradation of microbial flora if used as an exclusive ingredient in the diet of animals. An increase of fiber content in the plant indicates an increase in the cell wall, which improves the ruminal fermentation and feed digestibility for the ruminants $[50,53]$.

The higher crude protein $(\mathrm{CP})$ content obtained in the WH irrigation-fertilization in the cultivation of cactus pear was because the plant in this treatment suffered water stress, which in forage plants can increase their cellular content, especially CP content $[54,55]$. The application of fertilizers via localized irrigation is recommended, as small doses of micronutrients in a small volume of soil because conventional dosage can be phytotoxic. In the present study, the reduction in protein concentration was very small, which may be corrected when formulating animal diets.

\section{Conclusions}

The use of the commercial hydrogel polymers from polyacrylamide compounds and test hydrogel from natural $O$. phalerata fiber improved growth and chemical composition in the cactus pear plants in pots, particularly of the "Doce" and "Gigante" genotypes.

However, the irrigation-fertilisation with test hydrogel from copolymerized natural fiber from the mesocarp of Orbignya phalerata (babassu fruit) and presents similar production potential for cactus pear cultivation, compared to commercial hydrogel polymers from polyacrylamide compounds. Moreover, it is eco-friendlier with environmental and economic advantages due to the use of natural fibres. With the use of test hydrogel from natural O. phalerata fibre, water can be saved and thus contribute to the environment.

The test hydrogel from natural O. phalerata fibre has potential for hydration and fertilization of cactus pear plants and it should be tested as irrigation-fertilization in other plant cultures. 
Field studies with a longer duration and repetition in time should be conducted with these cactus pear species, to obtain a more accurate recommendation for the use of this test hydrogel.

Author Contributions: E.C.S.-F. and L.B. contributed in funding acquisition, project administration, and supervision; R.E. and R.R. contributed in the supervision, conceptualization, investigation and methodology; J.P.F. contributed in the data curation and software; M.S., R.M., H.R.S. and L.M.L.N. contributed application and execution of field tests and interpretation of analysis; R.E. and M.S. contributed in the writing-original draft; and L.B. realized writing - review \& editing. All authors have read and agreed to the published version of the manuscript.

Funding: This research received no external funding from the National Council for Scientific and Technological Development (Brazil).

Acknowledgments: This research was supported by the Coordination for the Improvement of Higher Education Personnel (CAPES), Brazilian National Council for Scientific and Technological Development (CNPq) with Grants Number 441321/2017-3, and Piauí State Research Support Foundation (FAPEPI).

Conflicts of Interest: The authors declare no conflict of interest.

\section{References}

1. Souza, A.J.J.; Guimarães, R.J.; Colombo, A.; Santana, J.A.V. Quantitative analysis of growth in coffee plants cultivated with a water-retaining polymer in an irrigated system. Rev. Ciênc. Agron. 2016, 47, 162-171. [CrossRef]

2. Vicente, M.R.; Mendes, A.A.; Silva, F.; Oliveira, F.R.; Mota Júnior, M.G.; Lima, V.O.B. Use of hydro absorbent gel associated with irrigation in eucalyptus plantation. Rev. Bras. Agric. Irrig. 2015, 5, 344-349.

3. Fajardo, L.; Rodriguez, J.P.; González, V.; Briceño-Linares, J.M. Restoration of a degraded tropical dry forest in Macanao, Venezuela. J. Arid Environ. 2013, 88, 236-243.

4. Pontes Filho, R.A.; Gondim, F.A.; Costa, M.C.G. Seedling growth of tree species under doses of hydrogel and two levels of luminosity. Rev. Árvore. 2018, 42, e420112. [CrossRef]

5. Cock, L.S.; Guancha-Chalapud, M.A. Natural fibers for hydrogels production and their applications in agriculture. Acta. Agron. 2017, 66, 495-505.

6. Rodriguez, A.; Jose, V.; Daniel, D.; Viviane, M.; Lavinia, A. Desarrollo de un material compuesto de fibras de henequén utilizando uma matriz termofija development of composite with henequen's fibres and termofix matrix. Ing. Mecánic. 2014, 17, 264-272.

7. Thakur, V.K.; Thakur, M.K. Processing and characterization of natural cellulose fibers/thermoset polymer composites. Carbohyd. Polym. 2014, 109, 102-117. [CrossRef]

8. Thomas, S.; Paul, S.A.; Pothan, L.A.; Deepa, B. Chapter 1: Natural fibres: Structure, properties and applications. In Bio-and NanoPolymer Composites; Springer: Berlin, Germany, 2011; pp. 1-42.

9. Amorim, E.; Matiasm, J.E.F.; Coelho, J.C.U.; Campos., A.C.L.; Stahlke, H.J., Jr.; Timi, J.R.R.; Rocha, L.C.A.; Moreira, A.T.R.; Rispoli, D.Z.; Ferreira, L.M. Topic use of aqueous extract of Orbignya phalerata (babassu) in rats: Analysis of it's healing effect. Acta Cir. Bras. 2006, 21, 67-76. [CrossRef]

10. Lorenzi, H.; Souza, H.M.; Medeiros Costa, J.T.; Cerqueira, L.S.C.; Behr, N.V. Palmeiras no Brasil: Nativas e Exóticas; Editora Plantarum: Nova Odessa, SP, Brazil, 1996; 303p.

11. Navroski, M.C.; Araujo, M.M.; Fior, C.S.; Cunha, F.S.; Berghetti, Á.L.P.; Pereira, M.O. Reduction of manure and improvement of the characteristics of substrate using hydrogel in the seedling production of Eucalyptus dunnii maiden. Ci. Fl. 2015, 26, 1155-1165. [CrossRef]

12. Food and Agriculture Organization of the United Nations (FAO). Agroecologia Cultivo e Usos da Palma Forrageira Estudo da FAO em Proteção e Produção Vegetal; SEBRAE/PB: Paraíba, Brazil, 2001; pp. 132-216.

13. Sáenz, C.; Sepúlveda, E.; Matsuhiro, B. Opuntia spp. mucilage's: A functional component with industrial perspectives. J. Arid Environ. 2004, 57, 275-290. [CrossRef]

14. Saenz, C. Processing technologies: An alternative for cactus pear (Opuntia spp.) fruits and cladodes. J. Arid Environ. 2000, 46, 209-225. [CrossRef]

15. Macêdo, A.J.S.; Santos, E.M.; Araújo, G.G.L.; Edvan, R.L.; Oliveira, J.S.; Perazzo, A.F.; Sá, W.C.C.S.; Pereira, D.M. Silages in the form of diet based on spineless cactus and buffelgrass. Afr. J. Range For. Sci. 2018, 35, 1-9. [CrossRef] 
16. Mayer, J.A.; Cushman, J.C. Nutritional and mineral content of prickly pear cactus: A highly water-use efficient forage, fodder and food species. J. Agron. Crop. Sci. 2019, 205, 625-634. [CrossRef]

17. Alvares, C.A.; Stape, J.L.; Sentelhas, P.C.; Goncalves, J.L.M.; Sparovek, G. Köppen's climate classification map for Brazil. Meteorol. Z. 2013, 22, 711-728. [CrossRef]

18. Raij, B.V. Fertilidade do Solo e Adubação; Ceres: Piracicaba, Brazil, 1991; p. 343.

19. Martha, G.B., Jr.; Vilela, D.; Sousa, D.M.G. Cerrado: Uso Eficiente de Corretivos e Fertilizantes em Pastagens; Embrapa Cerrados: Planaltina, DF, Brazil, 2007; 224p.

20. Casaroli, D.; Lier, Q.J.V. Criteria for pot capacity determination. Rev. Bras. Ciênc. Solo. 2008, 32, 59-66. [CrossRef]

21. Cortázar, V.; Nobel, P.S. Prediction and measurement of high annual productivity for Opuntia ficus-indica. Agric. For. Meteorol. 1991, 56, 261-272.

22. Association of Official Analytical Chemistry (AOAC). Official Methods of Analysis, 19th ed.; Association of Official Analytical Chemistry: Washington, DC, USA, 2012.

23. Van Soest, P.J.; Robertson, J.B.; Lewis, B.A. Methods for dietary fiber, neutral detergent fiber, and nonstarch polysaccharides in relation to animal nutrition. J. Dairy Sci. 1991, 74, 3583-3597. [CrossRef]

24. Ferreira, D.F. Sisvar: A computer statistical analysis system. Ciênc. agrotec. 2011, 35, 1039-1042. [CrossRef]

25. Vieira, A.P.; Santana, S.A.A.; Bezerra, C.W.B.; Silva, H.A.S.; Chaves, J.A.P.; Melo, J.C.P. Silva Filho, E.C.; Airoldi, C. Copper sorption from aqueous solutions and sugar cane spirits by chemically modified babassu coconut (Orbignya speciosa) mesocarp. Chem. Eng. J. 2010, 161, 99-105. [CrossRef]

26. Vieira, A.P.; Santana, S.A.A.; Bezerra, C.W.B.; Silva, H.A.S.; Chaves, J.A.P.; Melo, J.C.P.; Silva Filho, E.C.; Airoldi, C. Eepicarp and mesocarp of babassu (Orbignya speciosa): Characterization and application in copper phtalocyanine dye removal. J. Braz. Chem. Soc. 2011, 22, 21-29. [CrossRef]

27. Silva Filho, E.C.; Santana, S.A.A.; Melo, J.C.P.; Oliveira, F.J.V.E.; Airoldi, C. X-ray diffraction and thermogravimetry data of cellulose, chlorodeoxycellulose and aminodeoxycellulose. J. Therm. Anal. Calorim. 2010, 100, 315-321. [CrossRef]

28. Teixeira, P.R.S.; Teixeira, A.S.D.N.M.; Farias, E.A.D.O.; Silva, D.A.D.; Nunes, L.C.C.; Leite, C.M.D.S.; Eiras, C. Chemically modified babassu coconut (Orbignya sp.) biopolymer: Characterization and development of a thin film for its application in electrochemical sensors. J. Polym. Res. 2018, 25, 127. [CrossRef]

29. Bortolin, A.; Aouada, F.A.; Longo, E.; Mattoso, L.H.C. Investigation of water absorption process in polysaccharide hydrogels: Effect of ionic charge, presence of salt, monomer and polysaccharide concentrations. Polimeros 2012, 22, 311-317. [CrossRef]

30. Nender, D.G.; Costa, F.R.; Edvan, R.L.; Souto Filho, L.T. Correlations and path analysis of morphological and yield traits of cactus pear accessions. Crop Breed Appl. Biotechnol. 2013, 13, 203-207. [CrossRef]

31. Cannazza, G.; Cataldo, A.; De Benedetto, E.; Demitri, C.; Madaghiele, M.; Sannino, A. Experimental assessment of the use of a novel superabsorbent polymer (SAP) for the optimization of water consumption in agricultural irrigation process. Water 2014, 6, 2056-2069. [CrossRef]

32. Silva, T.G.F.; Miranda, K.R.; Santos, D.C.; Queiroz, M.G.; Silva, M.C.; Cruz Neto, J.F.; Araújo, J.E.M. Cladode area of cactus forage clones: Modeling, analysis and applicability. Rev. Bras. Ciênc. Agrár. 2014, 9, 633-641.

33. Konzen, E.R.; Navroski, M.C.; Friederichs, G.; Ferrari, L.H.; Pereira, M.O.; Felippe, D. The use of hydrogel combined with appropriate substrate and fertilizer improve quality and growth performance of Mimosa scabrella Benth. Seedlings. Cerne 2017, 23, 473-482. [CrossRef]

34. Rodrigues, F.H.A.; Spagnol, C.; Pereira, A.G.B.; Fajardo, R.; Rubira, A.F.; Muniz, E.C.; Martins, A.F. Superabsorbent hydrogel composites with a focus on hydrogels containing nanofibers or nanowhiskers of cellulose and chitin. J. Appl. Polym. Sci. 2013, 131, 1-13. [CrossRef]

35. Azeem, B.; KuShaari, K.; Man, Z.B.; Basit, A.; Thanh, T.H. Review on materials and methods to produce controlled release coated urea fertilizer. J. Control. Release. 2014, 181, 11-21. [CrossRef]

36. Alves, F.G.S.; Carneiro, M.S.S.; Edvan, R.L.; Candido, M.J.D.; Furtado, R.N.; Pereira, E.S.; Neto, L.B.M.; Mota, R.R.M.; Nascimento, K.S. Agronomic and nutritional responses of Carajas elephant grass fertilized with protected and non-protected urea. Semina Ciênc. Agrár. 2018, 39, 2181-2189. [CrossRef]

37. Cavalcante, L.A.D.; Santos, G.R.A.; Silva, L.M.; Fagundes, J.L.; Silva, M.A. Response of cactus pear genotypes to different crop densities. Pesqui. Agropecu. Trop. 2014, 44, 424-433. [CrossRef] 
38. Souza, T.C.; Santos, M.V.F.; Júnior, J.C.B.; Lira, M.A.; Santos, D.C.; Cunha, M.V.; Lima, L.E.; Silva, R.R. Productivity and nutrient concentration in spineless cactos under different fertilizations and plant densities. Rev. Bras. Ci. Agr. 2017, 12, 555-560.

39. Lima, G.F.C.; Rego, M.M.T.; Dantas, F.D.G.; Lôbo, R.N.B.; Silva, J.G.M.; Aguiar, E.M. Morphological characteristics and forage productivity of irrigated cactus pear under different cutting intensities. Rev. Caatinga. 2016, 29, 481-488. [CrossRef]

40. Morais, J.E.F.; Silva, T.G.F.; Queiroz, M.G.; Araújo, G.G.L.; Moura, M.S.B.; Araújo Júnior, G.N. Hydrodynamic changes of the soil-cactus interface, effective actual evapotranspiration and its water efficiency under irrigation. Rev. Bras. Eng. Agríc. Ambient. 2017, 21, 273-278. [CrossRef]

41. Shackleton, R.T.; Witt, A.B.R.; Piroris, F.M.; Wilgen, B.W. Distribution and socio-ecological impacts of the invasive alien cactus Opuntia stricta in eastern. Africa. Biol. Invasions. 2017, 19, 2427-2441. [CrossRef]

42. Edvan, R.L.; Fernandes, P.D.; Carneiro, M.S.S.; Nender, D.G.; Araujo, J.S.; Andrade, A.P.; Souto Filho, L.T. Biomass accumulation and root growth of cactus pear in different harvest periods. Rev. Acad. Agrár. Ambient. 2013, 11, 373-381.

43. Craine, J.M.; Froehle, J.; Tilman, D.G.; Wedin, D.A.; Chapin, F.S. The relationships among root and leaf traits of 76 grassland species and relative abundance along fertility and disturbance gradients. Oikos 2003, 93, 274-285. [CrossRef]

44. Wendling, M.; Büchi, L.; Amossé, C.; Sinaj, S.; Walter, A.; Charles, R. Influence of root and leaf traits on the uptake of nutrients in cover crops. Plant Soil. 2016, 409, 419-434. [CrossRef]

45. Guilherme, M.R.; Aouada, F.A.; Fajardo, A.R.; Martins, A.F.; Paulino, A.T.; Davi, M.F.; Rubira, A.F.; Muniz, E.C. Superabsorbent hydrogels based on polysaccharides for application in agriculture as soil conditioner and nutrient carrier: A review. Eur. Polym. J. 2015, 72, 365-385. [CrossRef]

46. Rozo, G.; Bohorques, L.; Santamaría, J. Controlled release fertilizer encapsulated by a K-carrageenan hydrogel. Polimeros 2019, 29, 1-7. [CrossRef]

47. Laredo, M.A.; Simpson, G.D.; Minson, D.J. The potential for using n-alkanes in tropical forages as a marker for the determination of dry matter by grazing ruminants. J. Agr. Sci. 1991, 117, 355-361. [CrossRef]

48. Amorim, D.S.; Edvan, R.L.; Nascimento, R.R.; Bezerra, L.R.; Araujo, M.J.; Silva, A.L.; Diogenes, L.V.; Oliveira, R.L. Sesame production and composition compared to conventional forages. Chil. J. Agric. Res. 2019, 79, 586-595. [CrossRef]

49. Macedo Júnior, G.L.; Zanine, A.M.; Borges, I.; Pérez, J.R.O. Fiber quality for ruminant diets. Ci. Anim. 2007, 17, 7-17.

50. Mertens, D.R. Regulation of Forage Intake. In Forage Quality, Evaluation, and Utilization; Fahey, J.R., Ed.; American Society of Agronomy: Madison, WI, USA, 1994.

51. National Research Council (NRC). Nutrient Requirements of Dairy Cattle, 7th rev. edn.; Natl. Acad. Press: Washington, DC, USA, 2001.

52. Carvalho, C.B.M.; Edvan, R.L.; Carvalho, M.L.A.M.; Reis, A.L.A.; Nascimento, R.R. Uso de cactáceas na alimentação animal e seu armazenamento após colheita. Arch. Zootecn. 2018, 67, 440-446. [CrossRef]

53. Freitas, F.P.; Fonseca, D.M.; Braz, T.G.S.; Martuscello, J.A.; Santos, M.E.R. Forage yield and nutritive value of Tanzania grass under nitrogen supplies and plant densities. Rev. Bras. Zootecn. 2012, 41, 864-872. [CrossRef]

54. Silva, E.A.; Silva, W.J.; Barreto, A.C.; Oliveira, A.B., Jr.; Paes, J.M.V.; Ruas, J.R.M.; Queiroz, D.S. Chemical composition and photosynthetically active radiation of forage grasses under irrigation. Rev. Bras. Zootecn. 2012, 41, 583-591. [CrossRef]

55. Alves, F.A.L.; Andrade, A.P.; Bruno, R.L.A.; Silva, M.G.V.; Souza, M.F.V.; Santos, D.C. Seasonal variability of phenolic compounds and antioxidant activity in prickly pear cladodes of Opuntia and Nopalea genres. Food Sci. Technol. 2017, 37, 536-543. [CrossRef]

(C) 2020 by the authors. Licensee MDPI, Basel, Switzerland. This article is an open access article distributed under the terms and conditions of the Creative Commons Attribution (CC BY) license (http://creativecommons.org/licenses/by/4.0/). 